\title{
Chemical and Physical Properties of Coconut Fiber in Asphalt Mixture: A Review
}

\author{
Che Norazman Che Wan ${ }^{1}$, Tay Lay Ting ${ }^{2}$, Ramadhansyah Putra Jaya ${ }^{2}$ \\ ${ }^{1}$ Politeknik Ungku Omar, ${ }^{2}$ Universiti Teknologi Malaysia
}

\begin{abstract}
This paper is a review of the chemical and physical properties of coconut fiber in asphalt mixtures. Coconut fibers (CF) are natural fibers and also an agricultural waste, which is abundant after the extraction of juice and coconut fruit. Nowadays, CF has been studied for its potential use in the construction field to increase the strength of materials with its high tensile strength. Additionally, CF can also be one the materials in highway construction as it can improve the skid resistance of asphalt pavements. It was shown that CF treated with $\mathrm{NaOH}$ lowered the penetration value and increased the softening point of modified bitumen. Flow of bitumen also can be avoided at high mixing and compaction temperatures by adding $0.7 \%$ of $\mathrm{CF}$.
\end{abstract}

Key words: Coconut, Fiber, Asphalt mixture, Chemical properties, Physical properties

\section{I.0 INTRODUCTION}

Coconut fiber $(\mathrm{CF})$ is the tissue surrounding the seed of coconut palm which is thick, lightweight and has great abrasion resistance [1]. Coconut fiber is known as new waste materials that used in highway industry. CF has the lowest cellulose content percentage (36-43\%) but with twice amount of lignin (41$45 \%$ ) [2]. CF is a byproduct of coconut coir processing. It is extracted from the fibrous outer cover of the fruit of the coconut plant; mainly consist of lignin and cellulose. CF will acts as stabilizing additives when added into the asphalt mix around $180^{\circ} \mathrm{C}$ [3]. Some researchers have found that $\mathrm{CF}$ contains 36$43 \%$ of cellulose and $41-45 \%$ of lignin, which is twice the amount found in jute and sisal. This can improve its resistance and hardness of asphalt mixture [4]. The physical properties, structure and chemical properties will impact the value of $\mathrm{CF}$ as it will influence its breaking load and tensile strength [5]. Besides that, the lignin content in $\mathrm{CF}$ also can helps in resisting fungal and bacterial [6]. However, the good quality of CF can get from mature coconut shell [7]. CF has outstanding moisture absorption because the irregular of crack in the cross section surface made it has unique structure [8]. The unique structure also make it has good air permeability, moisture conductivity, susceptibility, viscoelasticity and rutting resistance as well as meliorate low temperature anti-cracking properties, durability, material toughness, fatigue life and lowering reflective cracking of asphalt concrete mixtures and pavements [4,9-12].

\subsection{OBJECTIVE OF THE STUDY}

The objectives of the present study are the following:

a) To review the chemical and physical properties of coconut fiber in asphalt mixtures.

b) To study and review the coconut fiber modified binder characteristics.

\subsection{RESEARCH FINDINGS}

\subsection{Chemical properties of $\mathbf{C F}$}

Munirah and Ahmad [13] reported that using $\mathrm{NaOH}$ can reduce the ability of $\mathrm{CF}$ to absorb water. Equation (1) shows the possible reaction mechanism during alkalized treatment base on stated by [13]. On the other hand, Figure 1 shows the tensile graph for the various treated CF composites [13]. It can be seen that $\mathrm{CF}$ treated with alkali $(\mathrm{NaOH})$ has higher tensile strength than untreated $\mathrm{CF}$ and Silane treated $\mathrm{CF}$. 
Fiber $-\mathrm{OH}+\mathrm{NaOH}$
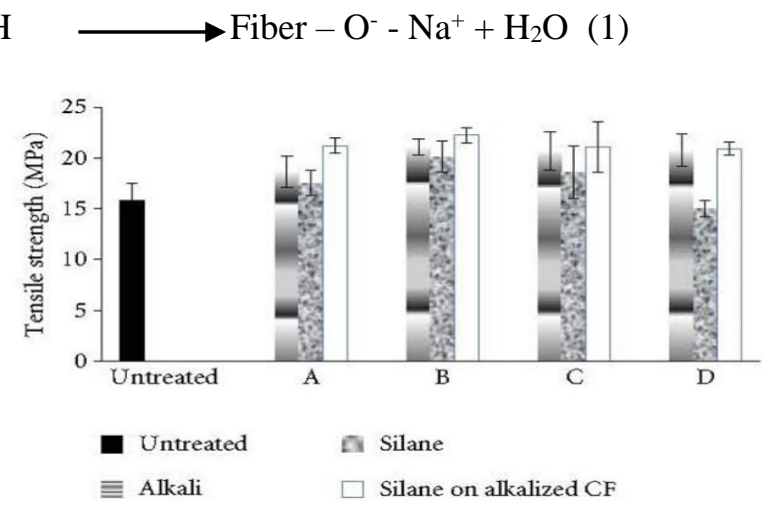

Figure 1. Tensile of various treated CF composites [13]

Figure 2 shows the water uptake graph for the various treated $\mathrm{CF}$ composites. The results showed that water uptake ability for $\mathrm{CF}$ treated with alkali is lower than untreated $\mathrm{CF}$ and Silane treated CF. It was concluded that CF treated with alkali can improve the tensile strength by reducing the water absorption ability [14].

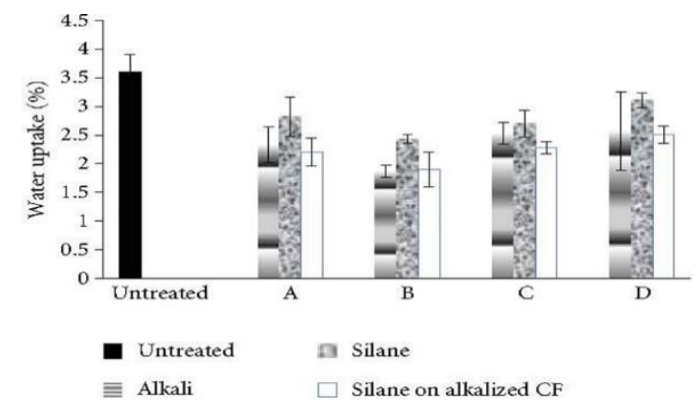

Figure 2. Water uptake graph for various treated CF composites from [13]

Figure 3 shows the scanning electron microscopy (SEM) of untreated CF and alkali treated CF. It shows that the CF has become rougher after alkali treatment and the micropores were more visible [15]. This is due to the alkali treatment has removed the hemicelluloses, amorphous waxy layer and also lignin from CF [16]. [16] also proved that treatment with $\mathrm{NaOCl}$ and $\mathrm{NaOH}$ affected the fiber cellulose content (Figure 4). CF provides many advantages when adding to asphalt mixture as it can reduce binder bleeds and enhance the macrotexture of coating [17]-[18]. It also behaves as stabilizing additives in asphalt mixture at around $180^{\circ} \mathrm{C}$ [3].

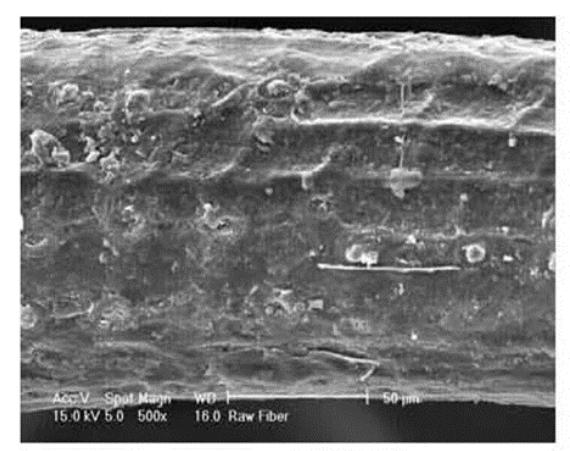

(a)

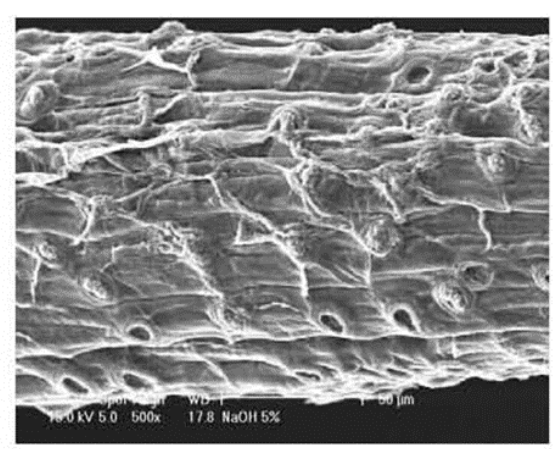

(b) 
Figure 3. SEM of (a) untreated CF and (b) treated CF [15]

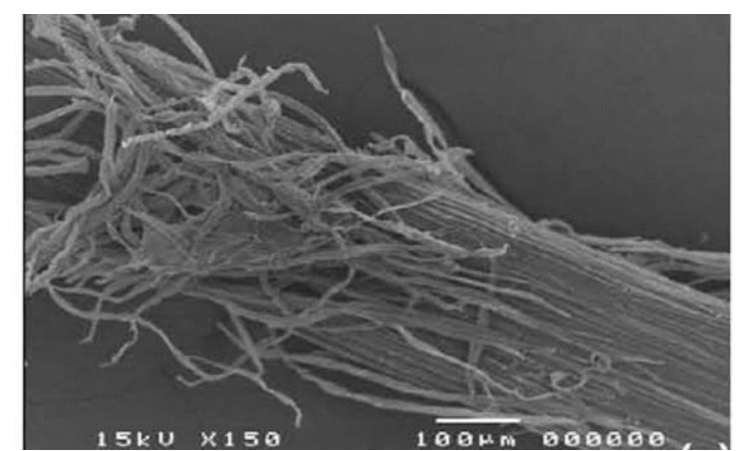

Figure 4. SEM of CF treated with $\mathrm{NaOCI} / \mathrm{NaOH}[16]$

\subsection{Physical properties of $\mathrm{CF}$}

CF has many advantages when adding to asphalt mixture as it can reduce binder bleeds and enhance the macro texture of coating [17]. It also behaves as a stabilizing additive in asphalt mixture at around $180^{\circ} \mathrm{C}$ [3]. [19] reported that the mechanical characteristics of pavement with tires also can be improved by the incorporation of CF. The discontinuous grain size in $\mathrm{CF}$ also helps in increase binder content as the aggregates are coated with a thicker film and hence prevent oxidation of asphalt mixtures and separation [20].

Meng, Guo and Han [8] reported that the irregular cracks in the cross section surface of CF improve the moisture absorption and air permeability. Also its unique structure amends the anti-cracking properties of asphalt mixture at low temperatures and also reduces the reflective cracking of asphalt pavement.

On the other hand, by adding CF into bitumen its brittleness can be reduced at low temperatures [21]. CF, also, enhances the range of temperatures that asphalt pavement could withstand without forfeiting its efficiency and without degradation [22]. CF also can reduce the flow of asphalt at high mixing temperatures and hence prevent bleeding and reduce air void clog of asphalt binders [23].

[7] reported two methods to mix fiber into bitumen for modification. Firstly, the wet process, which blends the fibers with asphalt binder prior to incorporating the binder into the mixture. Secondly, the dry process is when mixing the fiber with aggregate before adding asphalt. [24] concluded that there was no difference in the Marshall properties between the dry process and wet process. However, the dry process is easier to carry out and permits the distribution of fiber in the mixture. Besides that, there is no advantage carrying out the wet process since fibers would not melt in the asphalt and the field work normally uses the dry process.

[23] conducted a study on the application of coconut fibers in Stone Matrix Asphalt (SMA) mixtures. The research was conducted by using two different percentages of coconut fiber, which were $0.5 \%$ and $0.7 \%$. Table 1 shows the characteristics of CF used in this research. The flow parameter has been tested in this research and the results are shown in Table 2. This table shows that the flow parameter with fiber is lower than without fiber and $0.7 \%$ of $\mathrm{CF}$ has a lower flow parameter than $0.5 \%$ of CF. The results proved that CF can reduce the flow of asphalt binder and hence can decrease the clogging of air voids in the binder. Based on Table 1, it can be seen that the CF can increase the tensile strength by using Super pave compaction when compared to Marshall Mix design. 
Che Norazman, Tay Lay Ting \& Ramadhansyah/Journal of Engineering and Science Research,3(1) 2019, Pages:11-16

Table 1 Characteristics and properties of the coconut fiber [23]

Characteristics of granulated Results

\begin{tabular}{cc}
\hline $\begin{array}{c}\text { Average length of the granulated one } \\
\text { Average thickness }\end{array}$ & $10-20 \mathrm{~mm}$ \\
Amount (percentile in weight) & $0.1 \mathrm{~mm}$ \\
Ph & $0.5-0.7 \%$ \\
Electric Conductivity & 5.4 \\
Capacity of cationic exchange & $1.8 \mathrm{dS} / \mathrm{m}$ \\
Relation C/N & 92 \\
Specific mass & 132 \\
Water retention & $70 \mathrm{~g} / \mathrm{L}$ \\
Capacity of aeration & $538 \mathrm{ml} / \mathrm{L}$ \\
Porosity & $45.5 \%$ \\
\hline
\end{tabular}

Table 2. Result of flow parameter from [23]

\begin{tabular}{llll}
\hline \multirow{2}{*}{ Fiber } & \multirow{2}{*}{ Fiber content $(\%)$} & \multicolumn{2}{l}{ Flow parameter $(\%)$} \\
\cline { 3 - 4 } & & $\mathrm{T}=165^{\circ} \mathrm{C}$ & $\mathrm{T}=180^{\circ} \mathrm{C}$ \\
\hline \multirow{2}{*}{ Without fibers } & 0.0 & 1.06 & 0.70 \\
\hline \multirow{2}{*}{ Coconut } & 0.5 & 0.08 & 0.25 \\
& 0.7 & 0.04 & 0.09 \\
\hline \multirow{2}{*}{ Cellulose } & 0.3 & 0.01 & 0.03 \\
& 0.5 & 0.01 & 0.02 \\
\hline
\end{tabular}

Table 3. Result of static tensile strength and resilient modulus from [23]

\begin{tabular}{ccccccc}
\hline \multirow{2}{*}{ Mixture } & \multicolumn{2}{c}{ Tensile strength (MPa) } & \multicolumn{2}{c}{$\begin{array}{c}\text { Module of } \\
\text { Resilience(MPa) }\end{array}$} & $\begin{array}{c}\text { Relation Resilient } \\
\text { Modulus and Tensile } \\
\text { Strength }\end{array}$ \\
\cline { 2 - 7 } & Marshall & Superpave & Marshall & Superpave & Marshall & Superpave \\
\hline $\begin{array}{c}\text { SMA CAP 50/70 } \\
\text { without fiber }\end{array}$ & 0.78 & 0.91 & 2165 & 3121 & 2776 & 3429 \\
$\begin{array}{c}\text { SMA CAP 50/70 } \\
\text { Coconut fiber }\end{array}$ & 0.74 & 0.98 & 2784 & 3377 & 3745 & 3854 \\
\hline
\end{tabular}

\subsection{CONCLUSIONS}

CF has been studied for its potential use in the construction field to increase the properties of materials. In addition, CF can also be one the materials in highway construction as it can improve the skid resistance of asphalt pavements. It has been shown that when treated $\mathrm{CF}$ into $\mathrm{NaOH}$, the penetration value and softening point of modified bitumen was increased. On the other hand, different chemical treatments has been found that the most effective chemical that could reduce the water absorption yet does not change its properties. Finally, CF also should be used in various type of asphalt mixture as it can influence the flow parameter and also the skid resistance of the pavement.

\subsection{ACKNOWLEDGEMENT}

The support provided by Polytechnic Ungku Omar, Malaysian Ministry of Higher 
Education and Universiti Teknologi Malaysia in the form of a research grant number Q.J130000.2522.11H58 for this study is highly appreciated.

\section{REFERENCES}

[1] Wang, W.; Huang, G. (2009), Characterisation and utilization of natural coconut fibres composites. Materials \& Design, 30, (7), 2741-2744.

[2] Esmeraldo, M., Preparação de Novos. (2006). Compósitos Suportados em Matriz de Fibra Vegetal. Masters Degree, Departamento de Química Orgânica e Inorgânica, Universidade Federal do Ceará, Fortaleza-CE-Brazil 2006.

[3] Vasconcelos, K. L. (2004). Comportamento mecânico de misturas asfálticas a quente dosadas pelas metodologias marshall e superpave com diferentes granulometrias. 2004.

[4] Chen, H. and Q. Xu (2010). "Experimental study of fibers in stabilizing and reinforcing asphalt binder." Fuel 89(7): 1616-1622.

[5] Nanayakkara, N.; Ismail, M.; Wijesundara, R. (2005). Characterization and determination of properties of Sri Lankan coconut fibres. Journal of Natural Fibers 2005, 2, (1), 69-81.

[6] Frederick, T. and W. Norman (2004). "Natural fibers plastics and composites." EUA: Kluwer Academic Publishers.

[7] Abiola, O.; Kupolati, W.; Sadiku, E.; Ndambuki, J. (2014). Utilisation of natural fibre as modifier in bituminous mixes: A review. Construction and Building Materials 2014, 54, 305-312.

[8] Meng, J. G.; Guo, M. M.; Han, Y. H. (2012). Studies on Properties of the Coconut Carbon Fiber and Yarn. Advanced Materials Research 2012, 503, 1137-1141.

[9] Basri, H., M. Mannan and M. Zain (1999). "Concrete using waste oil palm shells as aggregate." Cement and Concrete Research 29(4): 619-622.

[10] Tan, I. A.; Wu, W.; Chan, R. A.; Lim, L. L. (2012). Effect of Mercerization and Acetylation on Properties of Coconut Fiber and its Influence on Modified Bitumen. UNIMAS e-Journal of Civil Engineering 2012, 5, (1).

[11] Al-Mansob, R. A., A. Ismail, M. A. Algorafi, M. H. Hafezi and M. S. Baghini (2013). "Comparison between Mixtures of Asphalt with Palm Oil Shells and Coconut Shells as Additives." Jurnal Kejuruteraan 25: 25-31.

[12] Kaur, M. and M. Kaur (2012). "A review on utilization of coconut shell as coarse aggregate in mass concrete." International journal of applied engineering research 7(11): 05-08.

[13] Munirah Abdullah, N.; Ahmad, I. (2012). Effect of chemical treatment on mechanical and watersorption properties coconut fiber-unsaturated polyester from recycled PET. ISRN Materials Science 2012.

[14] Bhaskar, J. and V. Singh (2013). "Water Absorption and Compressive Properties of Coconut Shell Particle Reinforced-Epoxy Composite." Journal of Materials Environment Science 1: 113-118.

[15] Bienia, J., M. Walczak, B. Surowska and J. Sobczaka (2003). "Microstructure and corrosion behaviour of aluminum fly ash composites." Journal of Optoelectronics and Advanced Materials 5(2): 493-502.

[16] Brígida, A.; Calado, V.; Gonçalves, L. (2010). Coelho, M., Effect of chemical treatments on properties of green coconut fiber. Carbohydrate Polymers 2010, 79, (4), 832838.

[17] Da Silva Dias'1, T. M.; da Silva, B.-H. A. (2014). Potential utilization of green coconut in asphalt paving in Rio de Janeiro and its benefits for the environment. 2014.

[18] Silva, G. G.; De Souza, D.; Machado, J. (2012). Hourston, D., Mechanical and thermal characterization of native Brazilian coir fiber Journal of applied polymer science 2000, 76, (7), 1197-1206.

[19] Beligni, M.; Villibor, D. F.; Cincerre, J. R. (2000). Misturas Asfálticas do Tipo SMA (Stone Matic Asphalt): Solução para Revestimentos de Pavimentos de Rodovias e Vias Urbanas de Tráfego Intenso. Anais da Reunião Anual de Pavimentação-32 ${ }^{\circ}$ RAPv. Brasil 2000, 1, 590-605.

[20] Neves Filho, C.; Bernucci, L.; Fernandes Jr, J. (2004). Avaliação de misturas asfálticas SMA produzidas com ligante Avaliação de misturas asfálticas SMA produzidas com ligante asfalto-borracha quanto ao módulo de resiliência, a resistência à tração e fadiga. $17 \mathrm{o}$. Encontro de Asfalto, Rio de Janeiro. $17^{\circ}$. Encontro de Asfalto 2004, 1, 128-136.

[21] Al-Hadidy, A.; Yi-Qiu, T. (2009). Mechanistic approach for polypropylene-modified flexible pavements. Materials \& Design 2009, 30, (4), 1133-1140.

[22] Lanchas, S. (1999). In Características del stone mastic asphalt SMA, Anais do Congresso Ibero-Latino americano Del Asfalto-10 CILA, 1999; 1999; pp 727-730.

[23] Do Vale, A. C.; Casagrande, M. D. T.; Soares, J. B. (2006). Application Of Coconut Fibers In SMA Mixtures. Pavements Mechanics Laboratory, Transport Engineering Department Federal University of Ceara, Brazil 2006.

[24] Abtahi, S.; Hejazi, S.; Sheikhzadeh, M.; Semnani, D. (2008). An investigation on the use of textile materials to mechanical reinforcement of asphalt-concrete (AC) structures and analysis of results by an artificial neural network (ANN). 4th Nat Cong on Civil Eng 2008. 